\title{
Correlation between Decreased Nuclear Factor Kappa Beta (NFK $\beta$ ), Kras, and Braf Genes' Expression and Enhanced Chemosensitivity of Human Squamous Cell Carcinoma Cells to 5-fluorouracil and/or Mesenchymal Stem Cells-derived Microvesicles
}

\author{
(1) Iman Mahmoud ABOUSHADY, (1) Ghada Abdel Aziz ABDEL-LATiF, ${ }^{2,3}$ (i) Dina SABRY, ${ }^{4}$ \\ (1) Sara EI MOSHY' \\ 'Department of Oral Biology, Cairo University Faculty of Dentistry, Cairo-Egypt \\ ${ }^{2}$ Department of Oral Pathology, Suez Canal University Faculty of Dentistry, Ismailia-Egypt \\ ${ }^{3}$ Department of Oral Basic and Clinical Sciences, Taibah University College of Dentistry, Madinah-Saudi Arabia \\ ${ }^{4}$ Department of Medical Biochemistry and Molecular Biology, Cairo University Faculty of Medicine, Cairo-Egypt
}

\begin{abstract}
OBJECTIVE
Oral squamous cell carcinoma (OSCC) comprises about $10 \%$ of head and neck cancer. 5-fluorouracil (5FU) is commonly used for the treatment of OSCC. However, it has many limitations due to its identified side effects. Therefore, this work compared squamous cell carcinoma (SCC) cells' chemosensitivity to 5-FU, mesenchymal stem cells-derived microvesicles (MVs), and their combination.
\end{abstract}

\section{METHODS}

Human SCC cell line (SCC152) was subjected to 5-FU or MVs or their combination for $24 \mathrm{~h}$ and 48 h. Inverted microscopic evaluation of apoptosis, MTT cell proliferation assay, DNA comet assay, and detection of NFK $\beta$, Kras, and Braf genes' expression were performed.

\section{RESULTS}

The combination group, compared to 5-FU or MVs treated groups, showed the most apparent apoptotic features. Cell proliferation was significantly decreased, while the tailed DNA\% was significantly increased in the combination group versus either the 5-FU or MVs groups. The combination group showed a significant decrease in NFK $\beta$, Kras, and Braf genes' expression than the 5-FU or MVs treated groups. The correlation between cell proliferation and the studied genes showed a very strong positive linear relationship, while a strong negative linear relationship existed between cell proliferation and tailed DNA\%.

\section{CONCLUSION}

The combination of MVs and 5-FU enhanced the genotoxicity and cytotoxicity of the SCC152 cell line compared to using either of them alone. Moreover, downregulation of NFK $\beta$, Kras, and Braf genes' expression was associated with enhanced apoptotic features, decreased cell proliferation, and enhanced tailed DNA\%.

Keywords: 5-Fluorouracil; braf; kras; microvesicles; NFK $\beta$; SCC152 cell line.

Copyright $\odot$ 2021, Turkish Society for Radiation Oncology 


\section{Introduction}

Oral squamous cell carcinoma (OSCC) is a pathological type of oral cancer, accounting for over $90 \%$ of oral cancers.[1] Oral cancer is the $8^{\text {th }}$ among the most common causes of cancer-related deaths worldwide. [2] Oral and oropharyngeal cancers are reported to account for approximately 220.000 new cases/year (5\% of all cancers) worldwide.[3] Molecular and genetic techniques have empowered us to untangle a portion of the basic events related to oral malignancy and precancer advancement.[4]

5-Fluorouracil (5-FU) is a chemotherapeutic drug commonly used for the treatment of solid cancers. 5 -FU interferes with nucleotide synthesis and is incorporated into DNA, which may have a mutational impact on both surviving tumor and healthy cells.[5] Despite its many advantages, clinical applications have been limited, as 5-FU treatment is associated with a high incidence of leukopenia, stomatitis, diarrhea, nausea, and vomiting. [6]

Fluoropyrimidines are intracellularly converted into the antifolate 5-fluorodeoxyuridine monophosphate that can form a covalent intermediate with folate-dependent enzyme thymidylate synthase.[7] Consequently, deoxythymine monophosphate formation from deoxyuridine monophosphate is inhibited, which results in an imbalance of the nucleotide pool that affects DNA synthesis. This imbalance is possibly through incorporating uracil, which has negative consequences on rapidly dividing cells such as cancer cells. Moreover, it has been proposed that 5-fluorodeoxyuridine triphosphate can be directly incorporated into genomic DNA as well.[8,9] Therefore, it is believable that fluoropyrimidines have mutagenic potential, although the mutational consequences of 5-FU treatments are still poorly understood.

Mesenchymal stem cells (MSCs) have been the focal point of unusual interest for regenerative treatment due to their capability to target the site of damage and their multilineage differentiation potential, and potent in vitro expansion.[10] The quality of MSCs can markedly change based on cell source, media composition, and cell passage, which is reflected as altered cell morphology, DNA abnormalities, cell senescence, decreased proliferation, and differentiation capacity, in addition to changed cellular plasticity. $[11,12]$ Variations in the quality of MSCs can influence reproducibility, creating discrepancies in in vivo outcomes, and eventually, clinical trials. $[13,14]$ Regarding the potential benefits of MSCs' use, Biancone et al.[10] have demonstrated that MSCs can improve chronic kidney damage through a paracrine activity represented by MSCs derived microvesicles (MVs).

Extracellular vesicles (EVs) are a heterogeneous group of membrane-bounded vesicles that are believed to be produced and secreted by apparently all cell types under physiological and pathological conditions, including tumors. MVs, a subtype of EVs, contain biologically active functional proteins and nucleic acids such as mRNA and microRNA. They could act as mediators of tissue biomechanical properties and as a bond between cancer multidrug resistance and increased tissue rigidity of the malignant mass.[15] MVs have been emerging as a novel bio-therapeutic platform to efficiently deliver therapeutic agents to treat a broad range of diseases, including cancer. Similarly, their presence in various body fluids makes them a potential biomarker for early diagnosis, prognostication, and cancer surveillance.[15,16]

Hence, the present study aimed to investigate the chemosensitivity of squamous cell carcinoma (SCC) cells to 5-FU, MSCs-MVs, or their combination.

\section{Materials and Methods}

\section{Cell Culture and Chemicals}

The human SCC cell line (SCC152) was obtained from the American Type Culture Collection (ATCC, CRL3240; Minnesota, USA). It was cultured in Dulbecco's Modified Eagle's Medium (DMEM) and enriched with $10 \%$ fetal bovine serum (FBS) in addition to a $1 \%$ concentration ratio of penicillin and streptomycin (Lonza, Verviers, Belgium). Cultures of SCC152 cells were preserved in a typical humidified incubator supplied with $5 \% \mathrm{CO}_{2}, 95 \%$ air at $37^{\circ} \mathrm{C}$. 5-FU was bought from SigmaAldrich Chemical Co., St. Louis, Mo, USA. MVs were prepared and derived from adipose MSCs. 5-FU and MVs were freshly solubilized in phosphate buffer saline (PBS). Our studied groups involved: SCC152, SCC152+5-FU, SCC152+MVs, and SCC152+5-FU+MVs.

\section{MVs Isolation}

MVs were obtained from supernatants of human adipose MSCs (hAMSCs). Briefly, hAMSCs were cultured in DMEM without FBS and $0.5 \%$ human serum albumin (Sigma-Aldrich) was added overnight. The viability of the cell-culture overnight was $>99 \%$, as detected by trypan blue exclusion. The conditioned medium was collected and stored at $-80^{\circ} \mathrm{C}$. The medium was centrifuged at $2000 \mathrm{~g}$ for $20 \mathrm{~min}$ to remove debris, and then ultra-centrifuged at 100,000 $\mathrm{g}$ in a SW41 swing rotor (Beckman Coulter, Fullerton, CA, USA) for 1 $\mathrm{h}$ at $4^{\circ} \mathrm{C}$. MVs were washed once with serum-free 
M199 (Sigma-Aldrich) containing $25 \mathrm{mM} \mathrm{4-(2-hy-}$ droxyethyl)-1-piperazineethanesulfonic acid ( $\mathrm{pH}=7.4)$ and submitted to the second ultracentrifugation in the same conditions. MVs were stored at $-80^{\circ} \mathrm{C}$ for the experiments. MVs were isolated from the hAMSCs under non-hypoxic or hypoxic conditions to quantify the protein content using Bradford method.[17]

\section{Morphological Assessment of Apoptosis}

Morphological apoptotic changes of the cultured cells were assessed using a phase-contrast inverted microscope (Leica DMI 3000B, Germany) at $\times 200$ magnifications. In brief, $5 \times 10^{5}$ cells were incubated for $24 \mathrm{~h}$ and $48 \mathrm{~h}$ with or without the selected treatments in tissue culture dishes. The medium was discarded, and cells were washed once with PBS before observing the apoptotic cells.[18]

\section{MTT Cell Proliferation Assay}

Cytotoxicity of 5-FU, MVs, or their combination on SCC152 cells was assessed through colorimetric MTT assay. SCC 152 cells were grown at $37^{\circ} \mathrm{C}$ for $24 \mathrm{~h}$ and 48 $\mathrm{h}$ in 96-well plates and treated with 5-FU, MVs, or their combination. MTT stock solution $(100 \mu \mathrm{l} ; 2 \mathrm{mg} / \mathrm{ml}$ in PBS) was then added to each well for $4 \mathrm{~h}$ of incubation. Formazan was further added to each well for overnight incubation. Measuring each well's absorbance was performed on an ELISA plated reader at a wavelength of about $540 \mathrm{~nm}$.[19]

\section{DNA Comet Assay}

For the detection of DNA damage, DNA comet assay was applied as follows: First, cells were suspended in low melting point agarose at $37^{\circ} \mathrm{C}$, on microscopic slide covered with a cover slip, then gelled at $4^{\circ} \mathrm{C}$, and the cover slip was removed. DNA damaging for the prepared cells and their subsequent lysis was performed. The final step was electrophoresis, where the lysed cells were immersed in an electrophoresis solution, and an electric field of $300 \mathrm{~mA}$ and $25 \mathrm{~V}$ was applied. Afterward, the slides were washed with neutralizing buffer (0.4 M Tris, $\mathrm{pH} 7.5$ ), followed by ethanol to do fixation. Finally, DNAs were stained with ethidium bromide (60 $\mu \mathrm{l}$ of a $20 \mu \mathrm{l} / \mathrm{ml}$ ). Randomly chosen cells were measured by Comet Assay automatic image analysis system fitted with Leica fluorescence microscope.[20]

\section{Quantitative Real-Time Polymerase Chain Reaction (qRT-PCR)}

The effect of 5-FU, MVs or their combination on NFK $\beta$, Kras, and Braf genes' expression were assessed using
qRT-PCR. SCC152 cells at a concentration of $1 \times 10^{5}$ cells/well were grown in a 6 well plate at IC50 concentration of 5-FU, MVs, or both. Cells were washed with cold PBS, trypsinized, harvested, and centrifuged. Cells were suspended in $200 \mu \mathrm{l}$ cold RNA lysis buffer with 5 $\mu \mathrm{l}$ Rase $(20 \mu \mathrm{g} / \mathrm{ml})$ for $15 \mathrm{~min}$. The cells were chilled on ice and further subjected to RNA extraction and purification using Thermo Fisher Scientific Inc. Germany (Gene J.E.T., Kit, \#K0732) following the manufacturer's instructions. The yield of total RNA obtained was determined at 260 and $280 \mathrm{~nm}$ using Beckman dual spectrophotometer. Gene's expressions were determined using RT-PCR (Step One, version 2.1, Applied Biosystems, Foster City, USA). 1000 ng of the total RNA from each sample was used for cDNA synthesis followed by PCR amplification cycles using Sensi FAST $^{\text {tu }}$ SYBR $^{\circ}$ Hi-ROX One-Step Kit, catalog no.PI-50217 V, UK. The thermal cycling profile was $15 \mathrm{~min}$ at $45^{\circ} \mathrm{C}$ for cDNA synthesis, followed by $5 \mathrm{~min}$ at $95^{\circ} \mathrm{C}$ for reverse transcriptase inactivation and polymerase activation. PCR amplification 40 cycles were followed, consisting of 15 $s$ of DNA denaturation at $95^{\circ} \mathrm{C}, 20 \mathrm{~s}$ primers annealing at $55^{\circ} \mathrm{C}$, and $30 \mathrm{~s}$ at $72^{\circ} \mathrm{C}$ for the amplification step. Changes in each target gene expression were normalized relative to the mean critical threshold (CT) values of the housekeeping gene, Glyceraldehyde-3-phosphate dehydrogenase, by the $\Delta \Delta \mathrm{CT}$ method. Primer sequences for each gene are demonstrated in Table 1.

\section{Statistical Analysis}

All obtained data were implied using the statistical package SPSS version 22. Data were expressed as mean and standard deviation. Comparisons between groups were made using analysis of variance with multiple comparison post hoc tests when comparing more than two groups. Comparison between the two durations

\begin{tabular}{|c|c|c|}
\hline Table 1 & Primers sequence of all stud & d genes \\
\hline $\begin{array}{l}\text { Gene } \\
\text { symbol }\end{array}$ & $\begin{array}{l}\text { Primer sequence } \\
\text { from 5' to 3' }\end{array}$ & $\begin{array}{l}\text { Gene bank } \\
\text { accession number }\end{array}$ \\
\hline \multirow[t]{2}{*}{$N F K \beta$} & F: AACGGCCTTCTGCACAGCGG & \\
\hline & R: CCAGGTAACAGGGCGTGGCC & NM_001024872.1 \\
\hline \multirow[t]{2}{*}{ Kras } & F: AAAATGACTGAATATAAACTTGTGG & \\
\hline & R: CTCTATTGTTGGATCATATTCGTC & XM014544259 \\
\hline \multirow[t]{2}{*}{ Braf } & F: CTTCATGAAGACCTCACAGT & \\
\hline & R: CATCCACAAAATGGATCCAG & XM006185354 \\
\hline \multirow[t]{2}{*}{ GAPDH } & F: CCTCTACTGGCGCTGCCAAGGCT & \\
\hline & R: GTCCACCACTGACACGTTGG & NT009759 \\
\hline
\end{tabular}

NFK $\beta$ : Nuclear factor kappa beta; GAPDH: Glyceraldehyde 3-phosphate dehydrogenase 
within the same group was performed using a paired sample t-test. In addition, correlations between the quantitative variables: Cell proliferation, tailed DNA\%, NFK $\beta$, Kras, and Braf, were accomplished using Pearson correlation coefficient.[21]

\section{Results}

\section{Inverted Microscopic Results (Fig. 1)}

The inverted microscopic examination revealed that most of the control (untreated) SCC152 cells, at both $24 \mathrm{~h}$ and $48 \mathrm{~h}$, retained their original morphology and were highly cohesive as well as being adherent to the culture dishes. They displayed rounded or polyhedral morphology, with prominent nucleoli, and they maintained cell to cell contact. On the other hand, exposure of SCC152 cells to 5-FU resulted in typical apoptotic features such as rounding of cells, shrinkage, blebbing in the cell membrane, loss of adherence, and losing contact with neighboring cells. These features were more noticeable in the 5-FU group than in the MVs and were more enhanced in the combination group than in the 5-FU group.

\section{Statistical Results \\ MTT cell proliferation results}

At $24 \mathrm{~h}$ duration, a significant decrease in cell proliferation occurred in the 5-FU and combination groups compared to the control one $(\mathrm{p}<0.001)$. In contrast, in the MVs group, cell proliferation was insignificantly decreased than that in the control group. On the other hand, at $48 \mathrm{~h}$ duration, a significant decrease occurred in the 5-FU, MVs, and combination groups compared to the control one $(\mathrm{p}<0.001)$. Furthermore, at both durations, a significant increase in cell proliferation occurred in the MVs group compared to the 5-FU one, while a significant decrease was detected in the combination group compared to the MVs one $(\mathrm{p}<0.001)$ (Fig. 2a).

Comparing cell proliferation results at $24 \mathrm{~h}$ and $48 \mathrm{~h}$ durations in each group revealed that in the control group, a significant increase in cell proliferation was observed at $48 \mathrm{~h}$ duration compared to that at 24 $\mathrm{h}(\mathrm{p}=0.008)$. However, in the 5-FU, MVs, and combination groups, there was a significant decrease in cell proliferation at $48 \mathrm{~h}$ duration compared to that at $24 \mathrm{~h}$ $(\mathrm{p}<0.001)$ (Fig. 2b).

\section{DNA comet assay (tailed DNA\%) results}

At both $24 \mathrm{~h}$ and $48 \mathrm{~h}$ durations, a significant increase in tailed DNA\% occurred in the 5-FU, MVs,
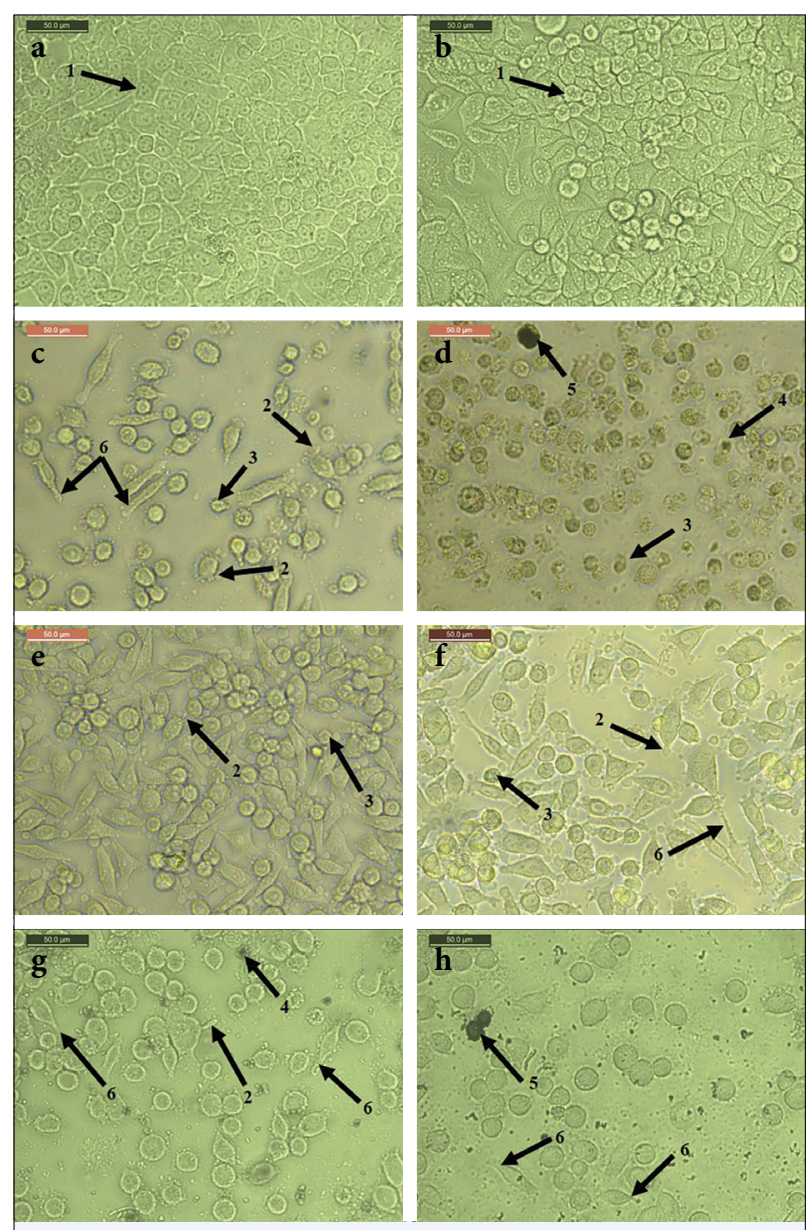

Fig. 1. Photomicrographs showing morphological changes of SCC152 in the control group at $24 \mathrm{~h}$ and 48 $\mathrm{h}$ respectively ( $\mathrm{a}$ and $\mathrm{b}$ ), 5-fluorouracil group at 24 $\mathrm{h}$ and $48 \mathrm{~h}$, respectively (c and $\mathrm{d}$ ), microvesicles group at $24 \mathrm{~h}$ and $48 \mathrm{~h}$, respectively (e and f) and combination group at $24 \mathrm{~h}$ and $48 \mathrm{~h}$, respectively ( $g$ and h) (1) Control cell, (2) membrane blebbing, (3) cell shrinkage, (4) apoptotic bodies, (5) apoptotic cells, and (6) apoptotic spikes (Original magnification: $\times 200$; scale bars: $50 \mu \mathrm{m})$.

and combination groups compared to the control one $(\mathrm{p}<0.001)$. However, at both durations, a significant decrease in tailed DNA\% was observed in the MVs group compared to the 5-FU one, while a significant increase occurred in the combination group compared to the $5-\mathrm{FU}$ and MVs groups $(\mathrm{p}<0.001)$ (Fig. 3a).

Comparing results at $24 \mathrm{~h}$ and $48 \mathrm{~h}$ durations in each studied group revealed that in the control group, there was no significant difference between $24 \mathrm{~h}$ and $48 \mathrm{~h}$ duration $(\mathrm{p}=0.49)$. However, in the 5-FU, MVs, and combination groups, there was a 


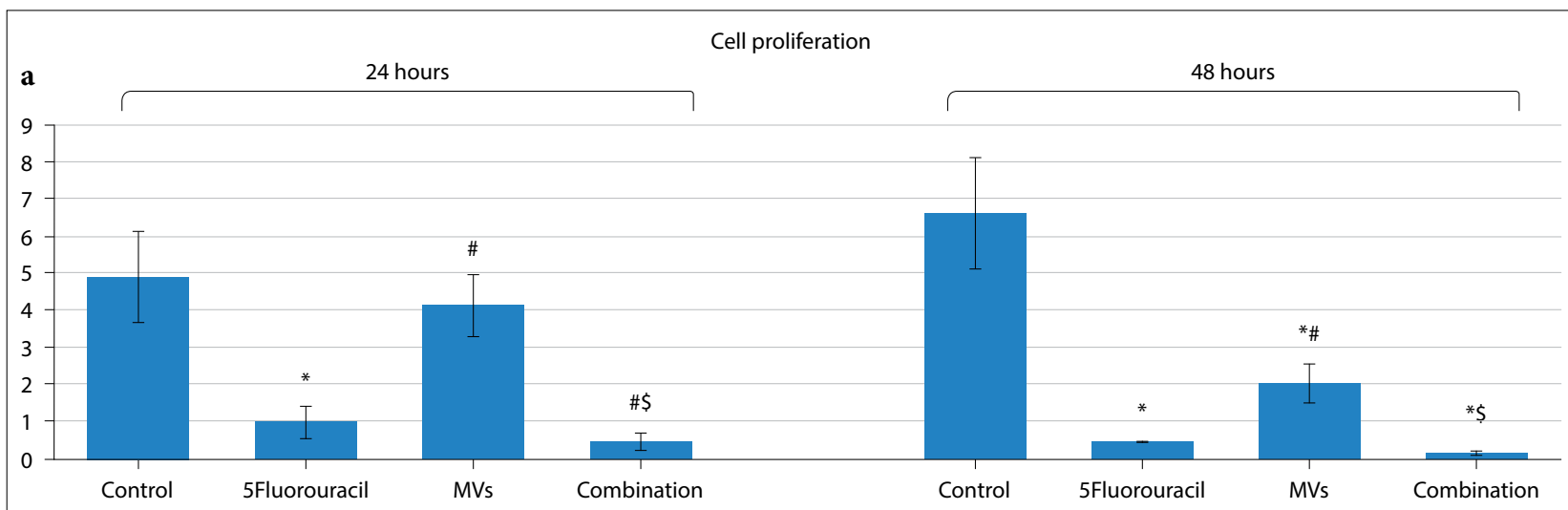

b Cell proliferation

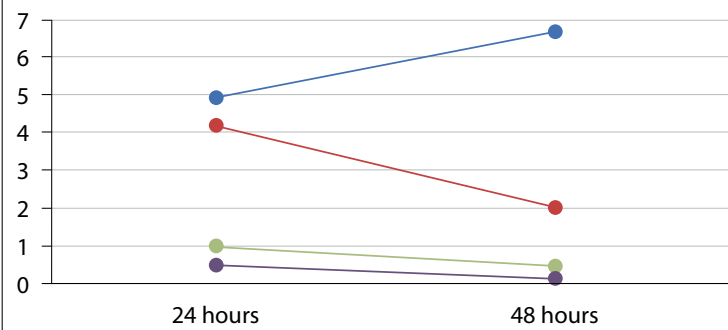

Control $\rightarrow$ 5Fluorouracil $-\bullet$ MVs $\rightarrow$ Combination
Fig. 2. (a) A graph comparing the means \pm SD of MTT cell proliferation assay among the four studied groups, $\mathrm{p}<0.05$ was significant $\left(^{*}\right)$ Denotes significant difference versus the control group (\#) Denotes significant difference versus 5-FU group (\$) Denotes significant difference versus MVs group. (b) A graph comparing the means \pm SD of MTT cell proliferation assay among the four studied groups, at $24 \mathrm{~h}$ and $48 \mathrm{~h}$ durations. MTT: 3-(4,5-Dimethylthiazol-2-Yl)-2,5-Diphenyltetrazolium Bromide, 5-FU: 5-fluorouracil, MVs: Microvesicles.

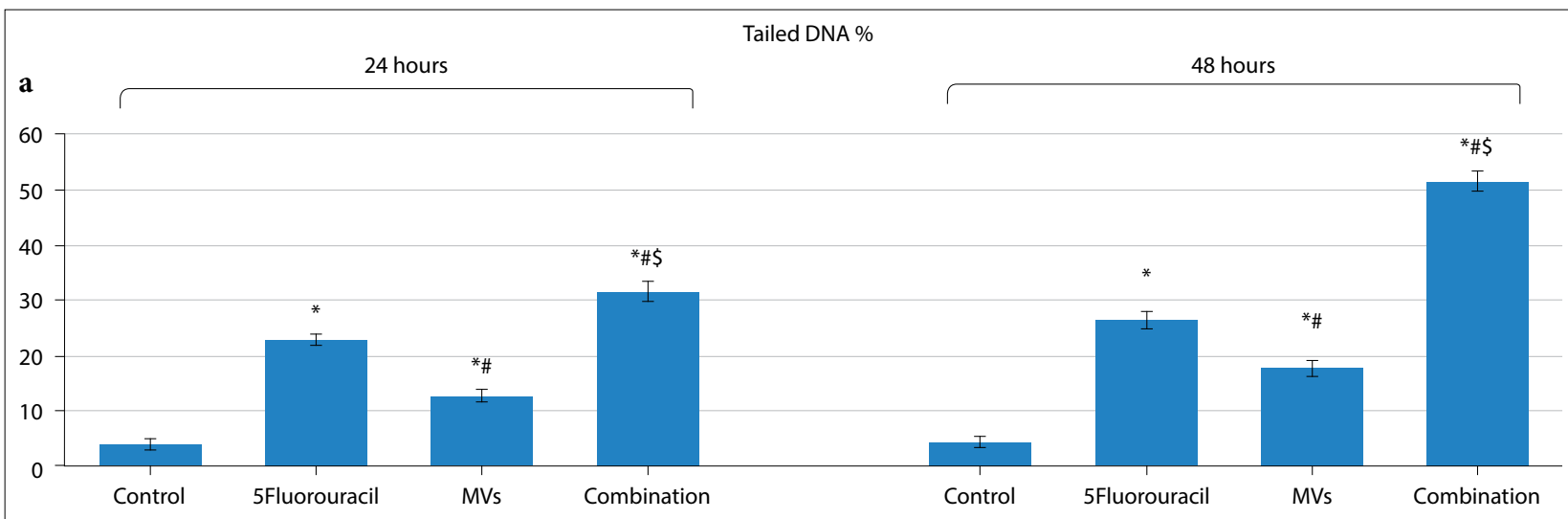

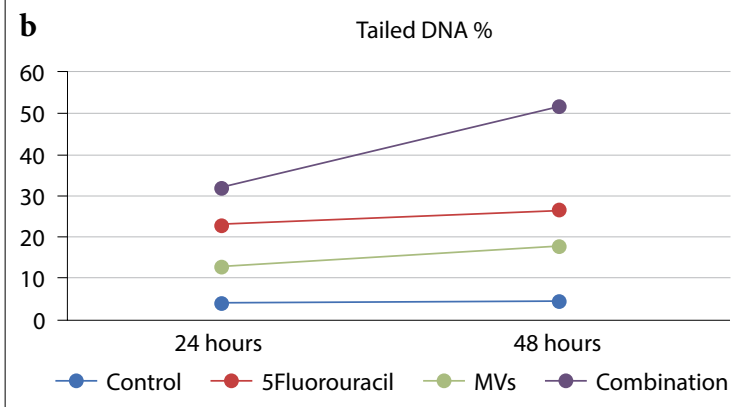

significant increase in the tailed DNA\% at $48 \mathrm{~h} \mathrm{du}-$ ration compared to $24 \mathrm{~h}(\mathrm{p}=0.04,0.001$, and 0.006 , respectively) (Fig. 3b).

\section{qRT-PCR results}

A significant decrease in NFK $\beta$ gene expression occurred in the 5-FU, MVs, and combination groups 
compared to the control group at $24 \mathrm{~h}(\mathrm{p}=0.017,0.016$, and 0.001 , respectively) and $48 \mathrm{~h}$ duration $(\mathrm{p}<0.001)$. On the other hand, at both $24 \mathrm{~h}$ and $48 \mathrm{~h}$, no significant difference existed between 5-FU, MVs, and combination groups $(\mathrm{p}>0.05)$ (Fig. 4a).

Regarding qRT-PCR results of Kras gene expression, at both $24 \mathrm{~h}$ and $48 \mathrm{~h}$ duration, a significant decrease in Kras gene expression occurred in the 5-FU, MVs, and combination groups compared to the control group $(\mathrm{p}<0.001)$. At $24 \mathrm{~h}$, there was a significant decrease in
Kras expression in the MVs group compared to the 5-FU group ( $\mathrm{p}=0.006)$. Similarly, a significant decrease in Kras expression occurred in the combination group compared to the MVs group ( $\mathrm{p}=0.001$ ). However, no significant difference was observed between the 5-FU, MVs, and combination groups at $48 \mathrm{~h}$ ( $\mathrm{p}>0.05$ ) (Fig. $4 \mathrm{~b}$ ).

Finally, the qRT-PCR results of Braf gene expression at $24 \mathrm{~h}$ and $48 \mathrm{~h}$ durations showed a significant decrease in Braf gene expression in the 5-FU, MVs, and combination groups compared to the control group $(\mathrm{p}<0.001)$.

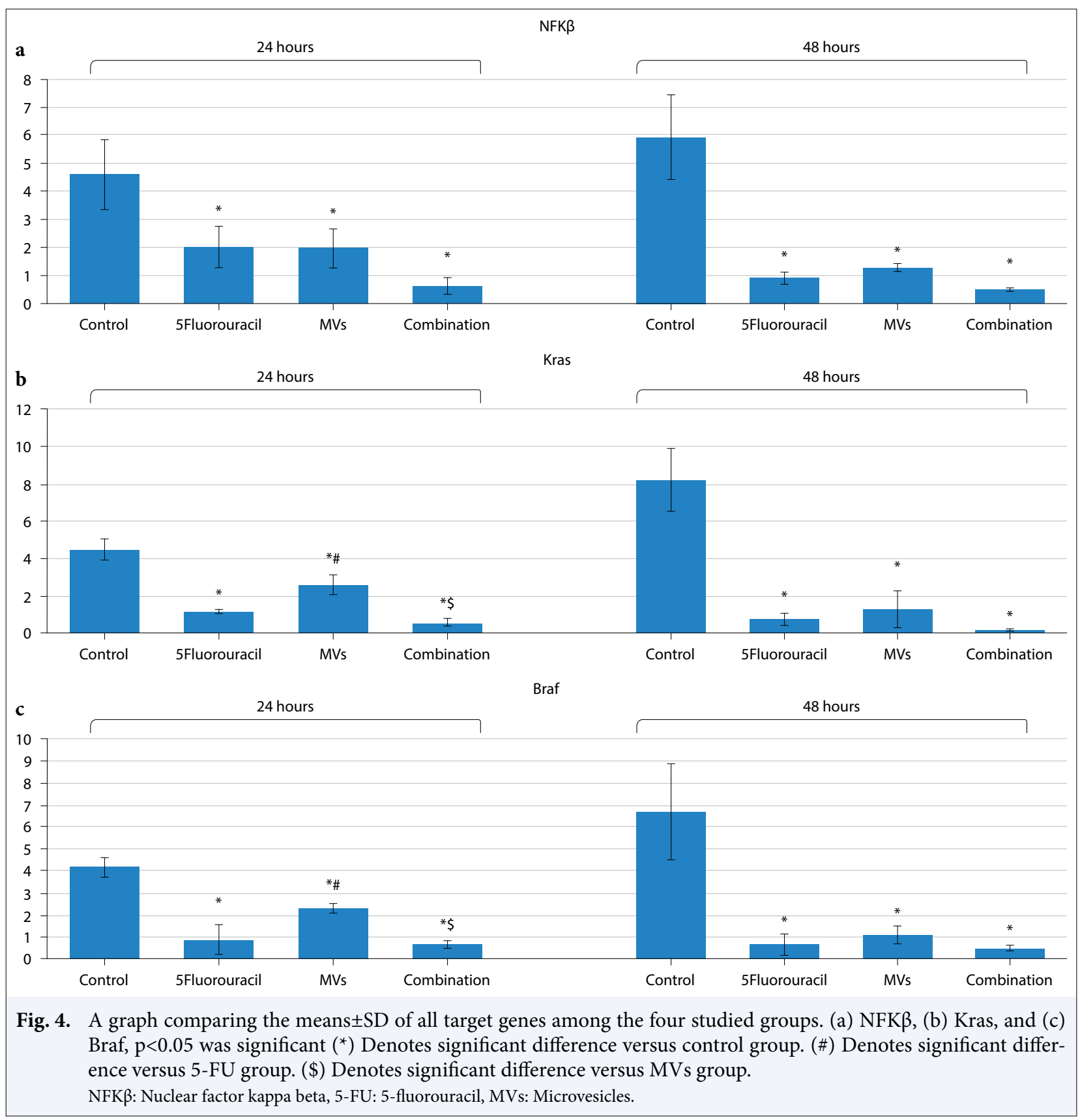


At $24 \mathrm{~h}$, a significant decrease in Braf expression was observed in the MVs group compared to the 5-FU one $(\mathrm{p}=0.01)$, likewise, a significant decrease in Braf expression occurred in the combination group compared to the MVs group ( $\mathrm{p}=0.001)$. However, at $48 \mathrm{~h}$ duration, no significant difference existed between the 5-FU, MVs, and combination groups ( $\mathrm{p}>0.05$ ) (Fig. 4c).

Besides, Comparing results of NFK $\beta$ at both durations in each studied group revealed that in the control, 5-FU, MVs, and combination groups, there was no significant differ- ence between $24 \mathrm{~h}$ and $48 \mathrm{~h}$ duration ( $\mathrm{p}=0.4,0.17,0.23$, and 0.5 , respectively) (Fig. $5 \mathrm{a}$ ).

Similarly, comparing results at $24 \mathrm{~h}$ and $48 \mathrm{~h}$ durations in each studied group revealed that in the control, 5-FU, and MVs groups; no significant difference existed between $48 \mathrm{~h}$ and $24 \mathrm{~h}$ durations ( $\mathrm{p}=0.4,0.09$, and 0.2 , respectively), while in the combination group; a significant decrease occurred at $48 \mathrm{~h}$ compared to 24 $\mathrm{h}(\mathrm{p}=0.049)$ (Fig. 5b).

Finally, comparing results at $24 \mathrm{~h}$ and $48 \mathrm{~h}$ durations in each studied group revealed no significant difference between both durations in the control, 5-FU, MVs, and combination groups ( $\mathrm{p}=0.14,0.7,0.058$, and 0.11 , respectively) (Fig. 5c).

\section{Results of correlations between quantitative variables} Correlation between cell proliferation and the genes: NFK $\beta$, Kras, and Braf revealed a very strong positive linear relationship $(\mathrm{p}<0.01$ and $\mathrm{r}=0.970,0.932$, and 0.912 , respectively) (Fig. 6a-c); while a strong negative linear relationship existed between cell proliferation and tailed DNA\% ( $\mathrm{p}<0.001$ and $\mathrm{r}=-0.776)$ (Fig. 6d).

On the other hand, correlation between tailed DNA\% and the genes: NFK $\beta$, Kras, and Braf revealed a strong negative linear relationship $(\mathrm{p}<0.01$ and $\mathrm{r}=-$ $0.753,-0.756$, and -0.707 , respectively) (Fig. 7a-c).

Finally, the correlation between NFK $\beta$ and the genes: Kras and Braf revealed a very strong positive linear relationship $(\mathrm{p}<0.01$ and $\mathrm{r}=0.975$ and 0.968 , respectively) (Fig. 8a, b). Similarly, the correlation between Kras and Braf genes' expression presented a very strong positive linear relationship where the $\mathrm{p}<0.01$ and $\mathrm{r}=0.975$ (Fig. 8c).

\section{Discussion}

Oral cancer is the most common head and neck cancer. Deficient early diagnosis and management yields high global morbidity and death where the 5-years survival level was $<63 \%$ for advanced oral and pharyngeal cancer.[22,23] The current study aimed to investigate the anti-cancerous effect of 5-FU, MSCs-derived MVs, or their combination on a SCC152 cell line.

In the present work, the inverted microscopic results revealed that exposure of the SCC152 cells to 5-FU resulted in typical apoptotic features such as rounding
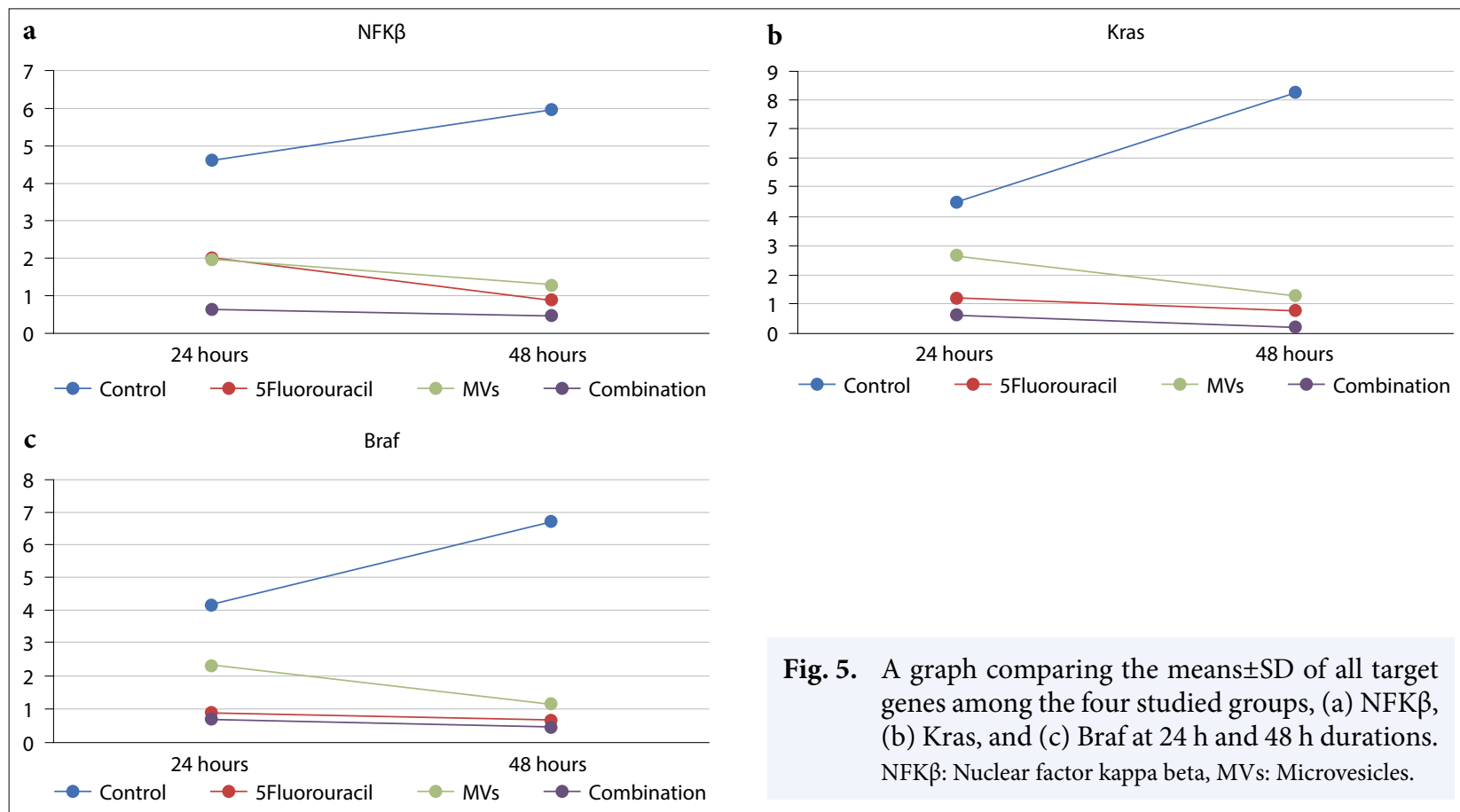

Fig. 5. A graph comparing the means $\pm S D$ of all target genes among the four studied groups, (a) NFK $\beta$, (b) Kras, and (c) Braf at $24 \mathrm{~h}$ and $48 \mathrm{~h}$ durations. NFK $\beta$ : Nuclear factor kappa beta, MVs: Microvesicles. 

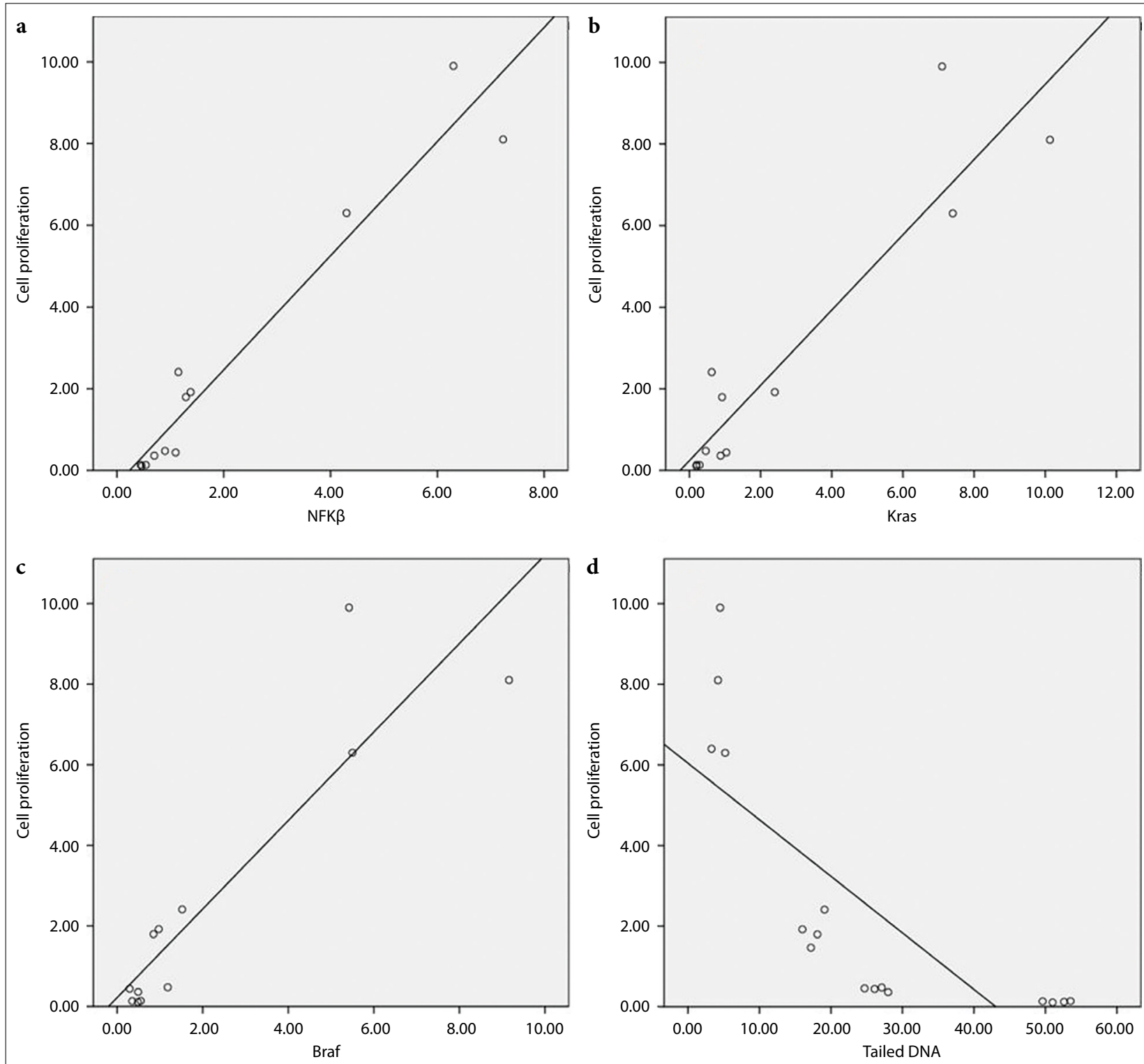

Fig. 6. A graph correlating between cell proliferation and (a) NFK $\beta$ gene expression, showing a strong positive linear relationship ( $\mathrm{p}<0.001$ and $\mathrm{r}=0.970)$, (b) Kras gene expression, showing a strong positive linear relationship $(\mathrm{p}<0.001$ and $\mathrm{r}=0.932)$, (c) Braf gene expression, showing a strong positive linear relationship $(\mathrm{p}<0.001$ and $\mathrm{r}=0.912)$, and $(\mathrm{d})$ tailed DNA\%, showing a strong negative linear relationship $(\mathrm{p}<0.001$ and $\mathrm{r}=-0.776)$.

NFK $\beta$ : Nuclear factor kappa beta.

of cells, shrinkage, blebbing in the cell membrane, loss of adherence, and losing contact with neighboring cells. These characteristic features were previously used to identify apoptosis.[24] Based on the morphological changes to define apoptosis using an inverted microscope, apoptotic features were obvious in the 5-FU group compared to the MVs and were more pronounced when 5-FU was combined with MVs. These results propose that the increased apoptotic features could reflect an improved anticancer effect achieved when adding the MVs to the 5-FU. This antitumor effect of MVs could be explained according to the results obtained by Fonsato et al.,[25] who demonstrated that human liver MSCs derived MVs inhibit the growth and induce apoptosis in hepatoma cells in vitro as well as in vivo. This effect was attributed to the miRNAs transferred by the MVs, which target migration inhibitory factor, Ras-related protein 14, multidrug resistance 

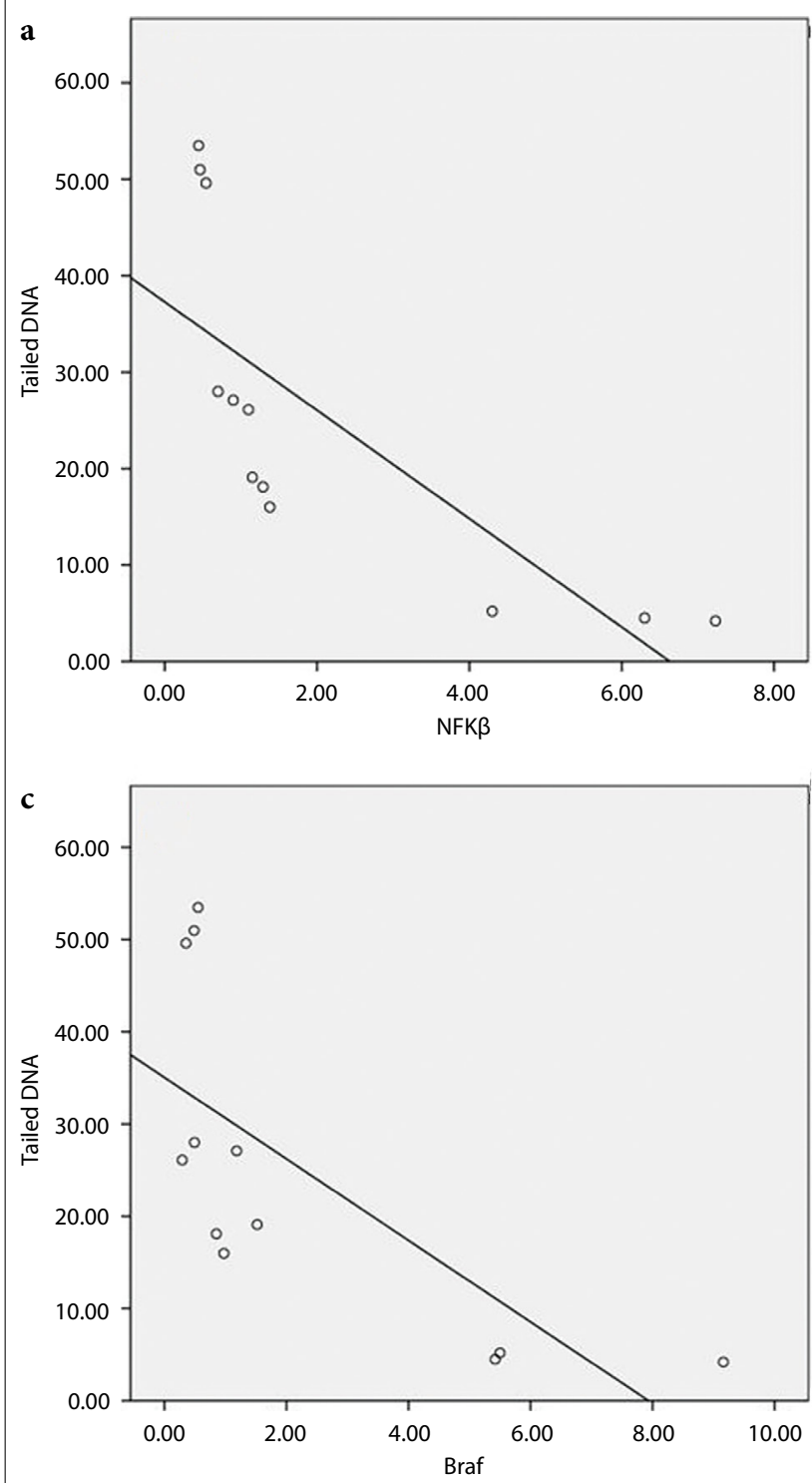

protein1, and interfere with proliferation, survival, besides drug-resistance signaling pathways. In addition, the antiproliferative and proapoptotic effects of human umbilical cord Wharton's jelly-MSCs effects on the bladder tumor cell line were suggested to be a result of MVs induced upregulation of p21, and p53 which in turn causes cell cycle arrest in the G0/G1 phase. Moreover, the upregulation of cleaved caspase 3 and Akt downregulation was believed to exert the MVs' proapoptotic effects.[26] However, contradictory results existed regarding the effect of MVs on tumor cells where Del Fattore et al.[27] reported that MVs isolated from bone marrow and cord blood-derived MSCs inhibited division and prompted apoptosis in glioblastoma cells. On the other hand, MVs isolated

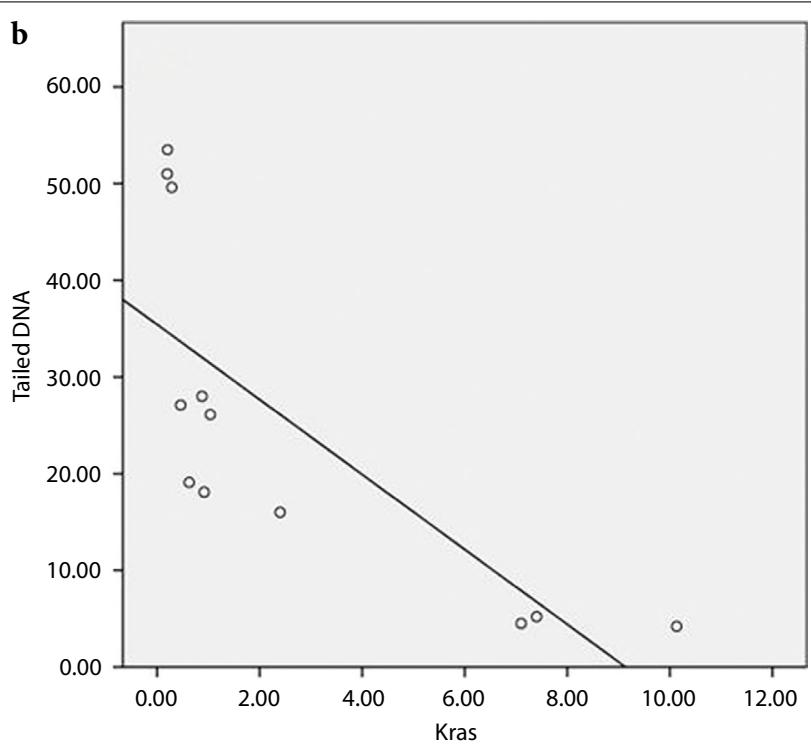

Fig. 7. A graph correlating between tailed DNA\% and (a) NFK $\beta$ gene expression, showing a strong negative linear relationship $(\mathrm{p}<0.01$ and $\mathrm{r}=-$ 0.753), (b) Kras gene expression, showing a strong negative linear relationship $(\mathrm{p}<0.01$ and $r=-0.756$ ), and (c) Braf gene expression, showing a strong positive linear relationship $(\mathrm{p}<0.01$ and $\mathrm{r}=-0.707)$.

NFK $\beta$ : Nuclear factor kappa beta. from adipose MSCs displayed an opposing effect as they stimulated tumor cells' proliferation.

In the herein study, the MTT assay results revealed that at both durations, 5-FU either alone or in combination with MVs exerted a significant cytotoxic effect on SCC152 cells compared to the untreated cells. In addition, at both $24 \mathrm{~h}$ and $48 \mathrm{~h}$ durations, the cytotoxic effect of 5-FU was significantly increased than in the MVs group and a significant cytotoxic effect was recorded in the combination group compared to the MVs one. Besides, comparing cell proliferation results at $24 \mathrm{~h}$ and $48 \mathrm{~h}$ durations in each group revealed that in the 5-FU, MVs, and combination groups, there was a significant cytotoxic effect on the SCC 152 cells at 48 $\mathrm{h}$ duration compared to that at $24 \mathrm{~h}$. 5 -FU exerts cyto- 

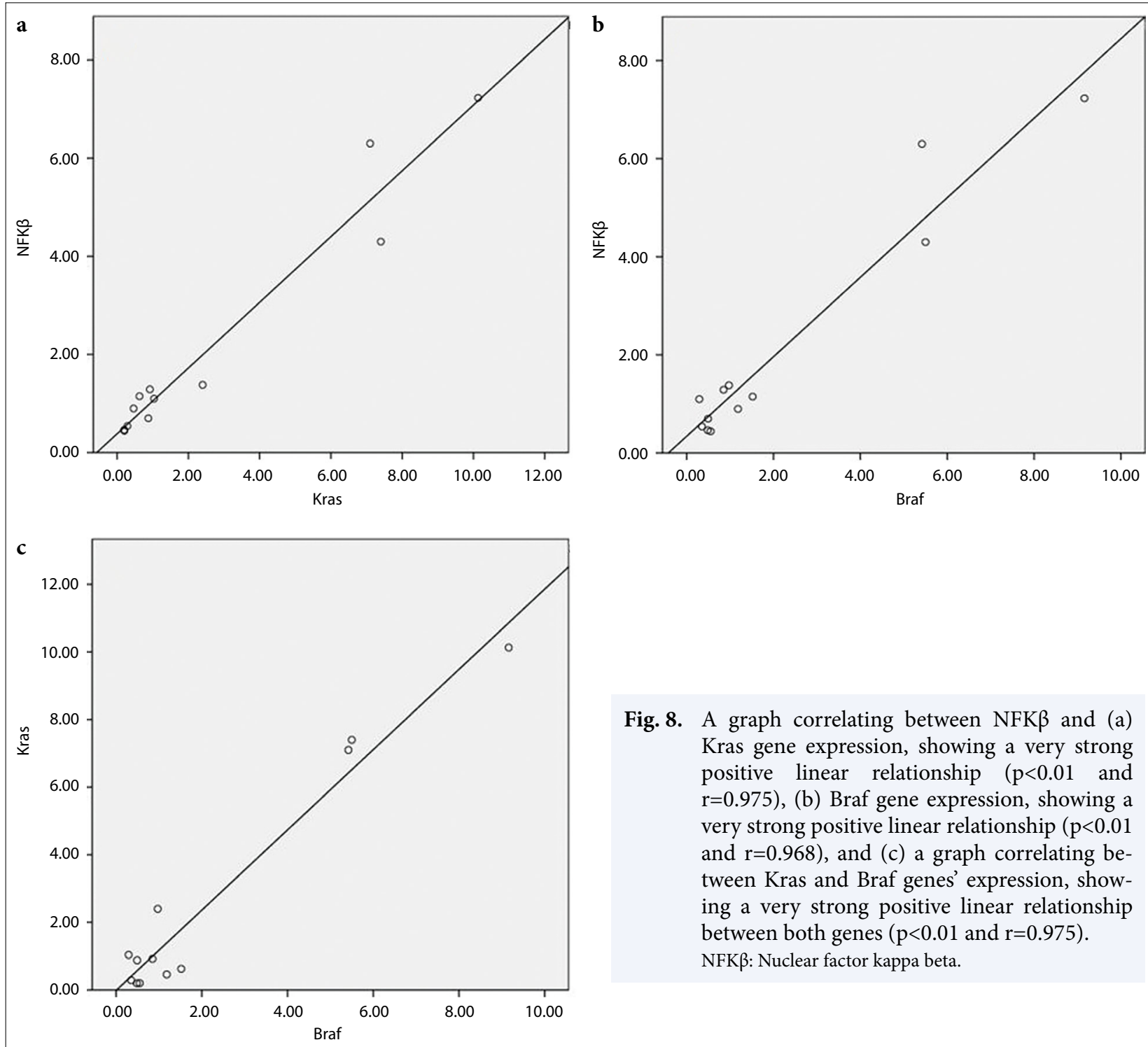

Fig. 8. A graph correlating between NFK $\beta$ and (a) Kras gene expression, showing a very strong positive linear relationship $(\mathrm{p}<0.01$ and $\mathrm{r}=0.975$ ), (b) Braf gene expression, showing a very strong positive linear relationship $(\mathrm{p}<0.01$ and $\mathrm{r}=0.968)$, and (c) a graph correlating between Kras and Braf genes' expression, showing a very strong positive linear relationship between both genes $(\mathrm{p}<0.01$ and $\mathrm{r}=0.975)$. NFK $\beta$ : Nuclear factor kappa beta.

toxic effects through its incorporation into DNA[28] and depending on the presence of p53 as well as the cleavage of Bid, a member of the pro-apoptotic Bcl-2 family.[29]

Comet assay is a sensitive and fast technique for evaluating DNA damage in single cells.[30] Hence, comet assay is used to analyze DNA damage and repair features in various tumor cells to react to diverse DNA damaging factors.[31] Single strand DNA breaks are caused by different elements, including reactive oxygen species, ultraviolet rays, X-rays, chemicals, or toxins.[32] This could support the obtained results in the current study, where the DNA comet results revealed genotoxic effects for 5-FU, MVs, or their combination on SCC152 cells at both $24 \mathrm{~h}$ and $48 \mathrm{~h}$ durations com- pared to the untreated cells. However, at both durations, the combined effect of both 5-FU and MVs resulted in a significant genotoxic effect of both treatments more than using either of them alone. The genotoxic effect of 5-FU was more potent than MVs as revealed by the significant increase in the tailed DNA\% in the 5-FU group compared to the MVs one. In addition, comparing results at both durations in each studied group revealed that in the 5-FU, MVs, and combination groups, there was a significant increase in the tailed DNA\% at $48 \mathrm{~h}$ duration compared to that at $24 \mathrm{~h}$; again supporting the genotoxic effect of the added treatments, which increased by increasing the time of exposure. Correlating cell proliferation MTT assay results and tailed DNA\% revealed a strong negative linear relationship since in- 
creased cell proliferation was associated with decreased tailed DNA\%. Thus, it could be concluded that 5-FU, either alone or combined with MVs, exerted significant cytotoxic and genotoxic effects compared to the untreated cells.

According to the current results, it could be evident that combining MVs and 5-FU resulted in decreased NFK $\beta$ expression compared to the control group and compared to using either of them alone. NFK $\beta$ is a proinflammatory transcription factor that plays a crucial role in the initiation and progress of head and neck carcinomas and OSCCs.[33] Increased NFK $\beta$ raises interleukin-6, which, in turn, enhances the expression of cycloxygenase-2 (COX-2). COX-2 overexpression induces cancer progression by improving vascularity and cellular proliferation; while suppressing apoptosis. Furthermore, NFK $\beta$ is involved in tumor hematologic and lymphatic metastasis.[34] The reduced NFK $\beta$ expression decreased tumor cell proliferation, which indicates that increased NFK $\beta$ may result in low patient survival.[35] On the other hand, some studies demonstrated a tumor-suppressive role of NFK $\beta$ in certain cancers through transcriptional activation of the Fas ligand.[36] Moreover, the obstruction of NFK $\beta$ was reported to enhance oncogenic Ras-induced invasive epidermal growth, approximating squamous-cell carcinoma.[37] Therefore, the NFK $\beta$ pathway varies in different tumor cells, and thus, the complex role of the NFK $\beta$ pathway in cancer is still not clear.[38]

Kras belongs to small guanosine triphosphate (GTP) binding proteins known as the RAS superfamily or RAS-like GTP-ases. Mutations in the RAS gene family have been involved in up to $30 \%$ of whole human cancers. However, incidences of mutations in OSCCs are different (5-50\%) and seem to rely on the exact RAS gene and the geographic position of the investigated population.[39-41] Moreover, oncogenic stimulation of Kras was shown to be involved in the occurrence of oral cancer in mice and humans; this was verified through mouse modeling and subsequent RT-PCR[42] and cell transfection assays. [43] In the current study, at both durations, a significant decrease in Kras gene expression occurred in the 5-FU, MVs, and combination groups compared to the control group, with the least value in the combination group. These results could be attributed to the fact that activated Kras turns on many downstream signaling pathways, including PI3K/AKT, mitogen-activated protein kinase, and NFK $\beta$.[44] Kras activates NFK $\beta$, which is vital for cell viability and tumor transformation, along with concomitant p53 loss. [45] In addition, TANK-binding kinase 1 , a serine- threonine kinase capable of activating NFK $\beta$, was also reported as a synthetically lethal partner with mutant Kras.[46] This obvious association between NFK $\beta$ and Kras could support the potent, strong positive linear relationship demonstrated in the herein study between the expression of NFK $\beta$ and Kras genes.

Furthermore, the Braf gene expression at both durations showed a significant decrease in Braf gene expression in the 5-FU, MVs, and combination groups compared to the control group, being the least in the combination group. At $24 \mathrm{~h}$, a significant decrease in Braf expression was observed in the MVs group compared to the 5-FU one; likewise, a significant decrease in Braf expression occurred in the combination group compared to the MVs group. However, at $48 \mathrm{~h}$ duration, no significant difference existed between the 5-FU, MVs, and combination groups. Braf is a serine/ threonine kinase of the RAF family, which is an integral part of the RAS-RAF-MEK-ERK-MAP kinase pathway.[47] Kras functions in the identical pathway as Braf and is situated upstream to it,[48] which in turn, could explain the apparent strong linear relationship, in the current work, between Kras and Braf genes' expression. Braf mutation is observed in $15 \%$ of human malignancies, especially in malignant melanomas. [49] Mutations in both Kras and Braf in head and neck SCC (HNSCC) were investigated by Weber et al.[41] through PCR analysis of genomic DNA. They demonstrated a 3\% mutation frequency of Braf in the pharynx and hypopharynx samples but none in oral samples. They also recognized a $6 \%$ mutation incidence of Kras in the pharynx and floor of mouth samples. Moreover, Bissada et al.[50] demonstrated a Kras mutation in only seven of 195 HNSCC cases.

Conclusively, in the herein study, we demonstrated potent cytotoxic and genotoxic effects of 5-FU, which became enhanced when combined to MVs. Moreover, diminished cell proliferation was associated with enhanced tailed DNA\% as well as decreased NFK $\beta$, Kras, and Braf genes' expression, which was more noticeable in the combination group rather than the 5-FU or MVs groups.

\section{Conclusion}

5-FU exerted apparent genotoxic and cytotoxic effects on the SCC152 cell line. These effects were more pronounced when 5-FU was applied in combination with MVs. This study demonstrated the potential benefit of MVs usage to minimize the well-known side effects of 5 -FU in treating OSCCs. Further, downregulation of 
NFK $\beta$, Kras, and Braf genes' expression was associated with enhanced apoptotic features as well as decreased cell proliferation and enhanced tailed DNA\%.

However, further in vivo studies are recommended to validate the possible clinical application of MSCsderived MVs as an anti-cancerous therapy either alone or as an adjunctive therapy with chemotherapeutic agents. Of particular interest is the apparent correlation between the three studied genes and cell proliferation of cancer cells, which, consequently, could provide a rational basis for the potential prognostic value of these genes and their involved pathways in OSCC progression.

Peer-review: Externally peer-reviewed.

Conflict of Interest: All authors declared no conflict of interest.

Ethics Committee Approval: This study was conducted in accordance with local ethical rules. Ethics committee permission is not required as a cell line was used in this study.

Financial Support: None declared.

Authorship contributions: Concept - I.M.A., G.A.L., D.S., S.E.M.; Design - I.M.A., G.A.L., D.S., S.E.M.; Supervision - I.M.A., G.A.L., D.S.; Funding - I.M.A., G.A.L.; Materials - I.M.A., G.A.L., D.S.; Data collection and/or processing I.M.A., G.A.L., D.S., S.E.M.; Data analysis and/or interpretation - I.M.A., G.A.L., S.E.M.; Literature search - I.M.A., G.A.L., S.E.M.; Writing - I.M.A., G.A.L., S.E.M.; Critical review - I.M.A., S.E.M.

\section{References}

1. Johnson NW, Jayasekara P, Amarasinghe AH. Squamous cell carcinoma and precursor lesions of the oral cavity: epidemiology and aetiology. Periodontol 2011;57(1):19-37.

2. Patel RS, Clark JR, Dirven R, Wyten R, Gao K, O’Brien CJ. Prognostic factors in the surgical treatment of patients with oral carcinoma. ANZ J Surg 2009;79(12):19-22.

3. Rheeder P, Girdler-Brown B, Abram M, Van Heerden W, Van Zyl AW. Epidemiology of oral squamous cell carcinoma. SADJ 2012;67(10):550-3.

4. Zhang L, Cheung KJ Jr., Lam WL, Cheng X, Poh C, Priddy $\mathrm{R}$, et al. Increased genetic damage in oral leukoplakia from high risk sites: Potential impact on staging and clinical management. Cancer 2001;91(11):214855.

5. Christensen S, Van der Roest B, Besselink N, Janssen $\mathrm{R}$, Boymans S, Martens JW, et al. 5-Fluorouracil treatment induces characteristic $\mathrm{T}>\mathrm{G}$ mutations in human cancer. Nat Commun 2019;10(1):1-11.

6. Katona C, Kralovánszky J, Rosta A, Pandi E, Fónyad G, Tóth K, et al. Putative role of dihydropyrimidine dehydrogenase in the toxic side effect of 5-fluorouracil in colorectal cancer patients. Oncology 1998;55(5):46874.

7. Sommer H, Santi DV. Purification and amino acid analysis of an active site peptide from thymidylate synthetase containing covalently bound 5-fluoro2'-deoxyuridylate and methylenetetrahydrofolate. Biochem Biophys Res Commun 1974;57(3):689-95.

8. Pettersen HS, Visnes T, Vågbø $\mathrm{CB}$, Svaasand EK, Doseth B, Slupphaug G, et al. UNG-initiated base excision repair is the major repair route for 5-fluorouracil in DNA, but 5-fluorouracil cytotoxicity depends mainly on RNA incorporation. Nucleic Acids Res 2011;39(19):8430-44.

9. Huehls AM, Huntoon CJ, Joshi PM, Baehr CA, Wagner JM, Wang X, et al. Genomically incorporated 5-fluorouracil that escapes UNG-initiated base excision repair blocks DNA replication and activates homologous recombination. Mol Pharmacol 2016;89(1):53-62.

10. Biancone L, Bruno S, Deregibus MC, Tetta C, Camussi G. Therapeutic potential of mesenchymal stem cell-derived microvesicles. Nephrol Dial Transplant 2012;27(8):3037-42.

11. Ho PJ, Yen ML, Tang BC, Chen CT, Yen BL. $\mathrm{H}_{2} \mathrm{O}_{2}$ accumulation mediates differentiation capacity alteration, but not proliferative decline, in senescent human fetal mesenchymal stem cells. ARS 2013;18(15):1895-905.

12. Mimeault M, Batra SK. Recent insights into the molecular mechanisms involved in aging and the malignant transformation of adult stem/progenitor cells and their therapeutic implications. Ageing Res Rev 2009;8(2):94-112.

13. Galipeau J. The mesenchymal stromal cells dilemma does a negative phase III trial of random donor mesenchymal stromal cells in steroid-resistant graft-versus-host disease represent a death knell or a bump in the road? Cytotherapy 2013;15(1):2-8.

14. Kimbrel EA, Kouris NA, Yavanian GJ, Chu J, Qin Y, Chan A, et al. Mesenchymal stem cell population derived from human pluripotent stem cells displays potent immunomodulatory and therapeutic properties. Stem Cells Dev 2014;23(14):1611-24.

15. Pokharel D, Wijesinghe P, Oenarto V, Lu JF, Sampson DD, Kennedy BF, et al. Deciphering cell-to-cell communication in acquisition of cancer traits: Extracellular membrane vesicles are regulators of tissue biomechanics. OMICS 2016;20(8):462-9.

16. Khawar MB, Abbasi MH, Siddique Z, Arif A, Sheikh $\mathrm{N}$. An update on novel therapeutic warfronts of extracellular vesicles (EVs) in cancer treatment: Where we are standing right now and where to go in the future. 
Oxid Med Cell Longev 2019;2019:9702562.

17. Kang T, Jones TM, Naddell C, Bacanamwo M, Calvert JW, Thompson WE, et al. Adipose-derived stem cells induce angiogenesis via microvesicle transport of miRNA-31. Stem Cells Transl Med 2016;5(4):440-50.

18. Abdul Rahman SN, Abdul Wahab N, Abd Malek SN. In vitro morphological assessment of apoptosis induced by antiproliferative constituents from the rhizomes of Curcuma zedoaria. Evid Based Complement Alternat Med 2013;2013:257108.

19. Stockert JC, Horobin RW, Colombo LL, BlázquezCastro A. Tetrazolium salts and formazan products in cell biology: Viability assessment, fluorescence imaging, and labeling perspectives. Acta Histochem 2018;120(3):159-67.

20. Tice RR, Agurell E, Anderson D, Burlinson B, Hartmann A, Kobayashi H, et al. Single cell gel/ comet assay: Guidelines for in vitro and in vivo genetic toxicology testing. Environ Mol Mutagen 2000;35(3):206-21.

21. Chan YH. Biostatistics 102: Quantitative data-parametric a non-parametric tests. Singapore Med J 2003;44(8):391-6.

22. Marcazzan S, Varoni EM, Blanco E, Lodi G, Ferrari M. Nanomedicine, an emerging therapeutic strategy for oral cancer therapy. Oral Oncol 2018;76:1-7.

23. Mariño R, Haresaku S, McGrath R, Bailey D, Mccullough M, Musolino R, et al. Oral cancer screening practices of oral health professionals in Australia. BMC Oral Health 2017;17(1):1-9.

24. Moongkarndi P, Kosem N, Kaslungka S, Luanratana O, Pongpan N, Neungton N. Antiproliferation, antioxidation and induction of apoptosis by Garcinia mangostana (mangosteen) on SKBR3 human breast cancer cell line. J Ethnopharmacol 2004;90(1):161-6.

25. Fonsato V, Collino F, Herrera MB, Cavallari C, Deregibus MC, Cisterna B, et al. Human liver stem cell-derived microvesicles inhibit hepatoma growth in SCID mice by delivering antitumor microRNAs. Stem Cells 2012;30(9):1985-98.

26. Wu S, Ju GQ, Du T, Zhu YJ, Liu G-H. Microvesicles derived from human umbilical cord Wharton's jelly mesenchymal stem cells attenuate bladder tumor cell growth in vitro and in vivo. PLoS One 2013;8(4):e61366.

27. Del Fattore A, Luciano R, Saracino R, Battafarano G, Rizzo C, Pascucci L, et al. Differential effects of extracellular vesicles secreted by mesenchymal stem cells from different sources on glioblastoma cells. Expert Opin Biol Ther 2015;15(4):495-504.

28. Longley DB, Harkin DP, Johnston PG. 5-fluorouracil: Mechanisms of action and clinical strategies. Nat Rev Cancer 2003;3(5):330-8.

29. Sax JK, Fei P, Murphy ME, Bernhard E, Korsmeyer SJ, El-Deiry WS. BID regulation by p53 contributes to chemosensitivity. Nat Cell Biol 2002;4(11):842-9.

30. Saran R, Tiwari RK, Reddy PP, Ahuja YR. Risk assessment of oral cancer in patients with pre-cancerous states of the oral cavity using micronucleus test and challenge assay. Oral Oncol 2008;44(4):354-60.

31. McKenna DJ, McKeown SR, McKelvey-Martin VJ. Potential use of the comet assay in the clinical management of cancer. Mutagenesis 2008;23(3):183-90.

32. Mozaffarieh M, Konieczka K, Hauenstein D, Schoetzau A, Flammer J. Half a pack of cigarettes a day more than doubles DNA breaks in circulating leukocytes. Tob Induc Dis 2010;8(1):1-4.

33. Lee TL, Yang XP, Yan B, Friedman J, Duggal P, Bagain $\mathrm{L}$, et al. A novel nuclear factor- $\kappa \mathrm{B}$ gene signature is differentially expressed in head and neck squamous cell carcinomas in association with TP53 status. Clin Cancer Res 2007;13(19):5680-91.

34. Yan M, Xu Q, Zhang P, Zhou XJ, Zhang ZY, Chen WT. Correlation of NF- $\mathrm{kB}$ signal pathway with tumor metastasis of human head and neck squamous cell carcinoma. BMC Cancer 2010;10(1):1-13.

35. Anbo N, Ogi K, Sogabe Y, Shimanishi M, Kaneko T, Dehari $\mathrm{H}$, et al. Suppression of NF- $\mathrm{kB} / \mathrm{p} 65$ Inhibits the proliferation in oral squamous cancer cells. J Cancer Ther 2013;2013:32578.

36. Liu F, Bardhan K, Yang D, Thangaraju M, Ganapathy $\mathrm{V}$, Waller JL, et al. NF- $\kappa B$ directly regulates Fas transcription to modulate Fas-mediated apoptosis and tumor suppression. J Biol Chem 2012;287(30):25530-40.

37. Dajee M, Lazarov M, Zhang JY, Cai T, Green CL, Russell AJ, et al. NF- $\mathrm{kB}$ blockade and oncogenic Ras trigger invasive human epidermal neoplasia. Nature 2003;421(6923):639-43.

38. Shi Z, Hu Z, Chen D, Huang J, Fan J, Zhou S, et al. MicroRNA 200a mediates nasopharyngeal carcinoma cell proliferation through the activation of nuclear factor $\kappa$ B. Mol Med Report 2016;13(2):1732-8.

39. Anderson JA, Irish JC, McLachlin CM, Ngan BY. H-ras oncogene mutation and human papillomavirus infection in oral carcinomas. AOHNS 1994;120(7):755-60.

40. Das N, Majumder J, DasGupta U. Ras gene mutations in oral cancer in Eastern India. Oral Oncol 2000;36(1):76-80.

41. Weber A, Langhanki L, Sommerer F, Markwarth A, Wittekind C, Tannapfel A. Mutations of the BRAF gene in squamous cell carcinoma of the head and neck. Oncogene 2003;22(30):4757-9.

42. Caulin C, Nguyen T, Longley MA, Zhou Z, Wang XJ, Roop DR. Inducible activation of oncogenic K-ras results in tumor formation in the oral cavity. Cancer Res 2004;64(15):5054-8.

43. Howell R, Wong F, Fenwick R. A transforming Kirsten ras oncogene in an oral squamous carcinoma. J Oral Pathol Med 1990;19(7):301-5. 
44. Duran A, Linares JF, Galvez AS, Wikenheiser K, Flores JM, Diaz-Meco MT, et al. The signaling adaptor p62 is an important NF- $\kappa \mathrm{B}$ mediator in tumorigenesis. Cancer Cell 2008;13(4):343-54.

45. Chenette E. Cancer: A Ras and NF-kappaB pas de deux. Nat Rev Drug Discov 2009;8(12):932.

46. Barbie DA, Tamayo P, Boehm JS, Kim SY, Moody SE, Dunn IF, et al. Systematic RNA interference reveals that oncogenic KRAS-driven cancers require TBK1. Nature 2009;462(7269):108-12.

47. Mercer KE, Pritchard CA. Raf proteins and cancer: BRaf is identified as a mutational target. Biochim Biophys Acta 2003;1653(1):25-40.
48. Khosravi-Far R, White MA, Westwick JK, Solski PA, Chrzanowska-Wodnicka M, Van Aelst L, et al. Oncogenic Ras activation of Raf/mitogen-activated protein kinase-independent pathways is sufficient to cause tumorigenic transformation. Mol Cell Biol 1996;16(7):3923-33.

49. Davies H, Bignell GR, Cox C, Stephens P, Edkins S, Clegg S, et al. Mutations of the BRAF gene in human cancer. Nature 2002;417(6892):949-54.

50. Bissada E, Abboud O, Abou Chacra Z, Guertin L, Weng X, Nguyen-Tan PF, et al. Prevalence of K-RAS codons 12 and 13 mutations in locally advanced head and neck squamous cell carcinoma and impact on clinical outcomes. Int J Otolaryngol 2013;2013:848021. 